組織型別にみた早期胃癌のリンパ節転移に関する研究

\author{
関西医科大学外科 \\ 中根 恭司広実 伸郎 岡村 成雄 小島 善詞 \\ 朴常秀大草世雄 駒田 尚直 田中 完児 \\ 今林 伸康 土井康生 日置紘士郎 山本 政勝

\section{RELATIONSHIP BETWEEN HISTOLOGIC TYPE AND METASTATIC PATTERNS OF LYMPH NODES IN EARLY GASTRIC CANCER} \\ Yasushi NAKANE, Noburo HIROZANE, Shigeo OKAMURA, \\ Yoshifumi KOJIMA, Tsunehide BOKU, Tokio OKUSA, \\ Hisanao KOMADA, Kanji TANAKA, Nobuyasu IMABAYASHI \\ Yasuo DOI, Koshiro HIOKI and Masakatsu YAMAMOTO \\ Department of Surgery, Kansai Medical University
}

リンパ節郭清の立場から早期胃癌193例 ( $\mathrm{m}$ 癌86例, sm 癌107例) と $\mathrm{pm}$ 癌81例及対象として, 深達 度および組織型別に転移リンパ節の個数ならびに転移リンパ節の浸潤様式にどのよらな差があるかに ついて検討した， $\mathrm{m}, \mathrm{sm}, \mathrm{pm}$ 癌のリンパ節転移率はそれぞれ7\%,19\%，44\%であった。平均転移り ンパ節数は深達度に比例して増加し組織型別では早期胃癌に関しては分化型に多い傾向がみられた。 また転移りンパ節の漫潤様式については深達度が增すにつれて I 型 (辺縁洞型)が少なくなり II 型（髄 内洞型)，III型(全域型)が増加した。組織型別では分化型に I 型は少なく，II，III型が高率であった。 以上の成績より早期胃癌のうち分化型癌は転移リンパ節数が多く、リンパ節転移程度も強いため術中 操作の際には転移リンパ節からの 2 次的波及予防に注意を要する.

索引用語 : 早期胃癌, 早期胃癌の転移リンパ節数, 早期胃癌の転移リンパ節浸潤様式, 早期胃癌のリンパ節郭清

はじめに

近年, 胃癌切除症例に対する早期胃癌の占める割合 は診断技術の進歩とともに年々増加傾向を示して括 り，その治療成績はきわめて良好である。しかし早期 胃癌といえども少なからずリンパ節転移がみられ，ま た治癒切除例でも中には再発する症例もみられる。一 般に早期胃癌の再発は, (1)隆起型を呈する粘膜下層癌 (以下 sm 癌と略す), (2)分化型腺癌, (3)リンパ節転移陽 性, (4)脈管侵襲陽珄の症例に多くみられ, 再発形式と しては血行性転移 (肝転移) が最も多いとされてい る(1) . このため岩永ら"は早期胃癌でる sm癌になる とリンパ節転移率が高くなるので十分な郭清ととも

$<1988$ 年 3 月 9 日受理 $>$ 別刷請求先 : 中根 恭司 干570 守口市文園町 1 関西医科大学外科
K，肝転移予防のために開腹時まず胃から流出する 4 本の主要静脈を動脈とともに結紮して, 手術操作中に 癌が血行性転移を起こさないように注意する必要があ ると述べている。しかし主病巣からだけでなく郭清操 作中に転移リンパ節からの 2 次的波及の可能性もある ものと考えられる.

そこでリンパ節郭清の際の参考とすべく早期胃癌损 よび固有筇層癌(以下 pm 癌と略す)を対象として, 深 達度掞よび組織型別に転移リンパ節の個数ならびに転 移リンハ節の浸潤様式にどのような差があるかについ て検討してみた。

\section{対象と方法}

対象症例は昭和54年から62年 9 月までに当教室で切 除された単発早期胃癌193例 (粘膜内癌 (以下 $\mathrm{m}$ 癌と略 す） 86 例， $\mathrm{sm}$ 癌107例）と $\mathrm{pm}$ 癌81例を対象とした。 
表 1 深達度別リンパ節転移率（S. 54 62. 9)

\begin{tabular}{ccc}
\hline 梁達度 & 症例数 & 転移症例数 (\%) \\
\hline $\mathrm{m}$ & 86 & $6(7.0)$ \\
$\mathrm{sm}$ & 107 & $21(19.6)$ \\
\hline $\mathrm{m}, \mathrm{sm}$ & 193 & $27(14.0)$ \\
$\mathrm{pm}$ & 81 & $36(44.4)$ \\
\hline
\end{tabular}

図 1 転移リンパ節の浸潤様式分類

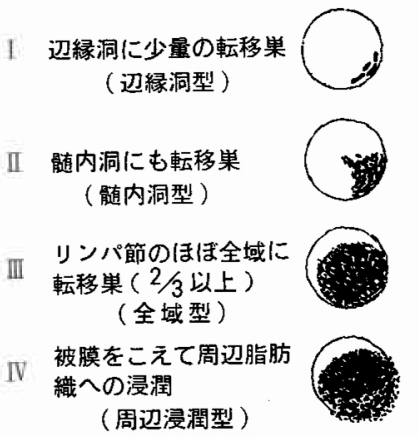

リンパ節転移率は $\mathrm{m}$ 癌 $7.0 \%, \mathrm{sm}$ 癌 $19.6 \%$ で早期胃

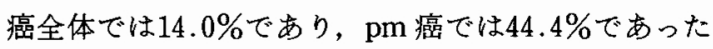
（表 1 ).リンパ節転移陽性例は全体で63例 ( $\mathrm{m}$ 癌 6 例, $\mathrm{sm}$ 癌21例, pm 癌36例) で, 転移リンパ節は250個 (m 癌10個, sm 癌56個, pm 癌184個)でった。リンパ節は 長軸方向の中心切片にて組織学的に検索を行い, 転移 リンパ節の浸潤様式は図 1 に示すごとく, 進展度に 従ってI〜IV型に分類した。

すなわち辺縁洞に少量の転移巣を認めるものをI 型 (辺縁洞型), 䯣内洞にも転移巣を認めるものをII型(髄 内洞型), リンパ節のほ注全域 $(2 / 3$ 以上) に転移巣を 認めるものをIII型(全域型), さらに被膜をこえて周辺 脂肪織への浸潤もみられるものをIV型 (周辺浸潤型) とした。

なお, 胃癌の病理は胃癌取扱い規約 ${ }^{5}$ に従い統計学 的検討は $\chi^{2}$ 検定, $\mathrm{t}$ 検定を用いて行った。

\section{成 績}

1）深達度別, 組織型別転移リンパ節数

まず深達度別よりみた転移リンパ節数についてみる と, $\mathrm{m}$ 癌では転移症例 6 例中転移リンパ節数は10個で 平均では1.7個であり, $\mathrm{sm}$ 癌では 21 例中 56 個, 平均 2.7 個で, 早期胃癌全体でみると平均 2.4 個であった。一方 $\mathrm{pm}$ 癌に関しては36例中184個で平均5.1個であり, 深 達度が増すにつれて平均転移リンパ節数も増加した。

また組織型別に分化型（pap, tub, muc) と低分化
表 2 深達度別・組織型別転移リンパ節数

\begin{tabular}{|c|c|c|c|c|}
\hline & \multicolumn{2}{|c|}{ 枟移症例数 } & 転移リンパ節数 & 平均枟移りンパ站数 \\
\hline $\mathrm{m}$ & \multicolumn{2}{|r|}{6} & 10 & $1.7 \longrightarrow$ \\
\hline sm & \multicolumn{2}{|c|}{21} & 56 & $2.7 \square$ \\
\hline m. sm & \multicolumn{2}{|c|}{27} & 66 & $2.47 *$ \\
\hline \multirow[t]{2}{*}{ pm } & \multicolumn{2}{|c|}{36} & 184 & $5.1]$ \\
\hline & \multicolumn{2}{|r|}{ 移症例数 } & 転移リンパ筑数 & 平均输移リンパ笛数 \\
\hline \multirow{2}{*}{$\mathrm{m}, \mathrm{sm}$} & 分 化 & 16 & 45 & 2.8 \\
\hline & 低分化 & 11 & 21 & 1.9 \\
\hline \multirow{2}{*}{$\mathrm{pm}$} & 分 化 & 28 & 116 & 4.1 \\
\hline & 低分化 & 8 & 68 & 8.5 \\
\hline
\end{tabular}

表 3 深達度別転移リンパ節漫潤様式

\begin{tabular}{|c|c|c|c|c|c|}
\hline & 1 & II & 111 & IV & it \\
\hline$m$ & $\begin{array}{c}7 \\
(70.0)\end{array}$ & 0 & $\begin{array}{c}2 \\
(20.0)\end{array}$ & $\begin{array}{c}1 \\
(10.0)\end{array}$ & 10 \\
\hline $\mathrm{sm}$ & $\begin{array}{c}29 \\
(51.8)\end{array}$ & $\begin{array}{c}11 \\
(19.6)\end{array}$ & $\begin{array}{c}15 \\
(26.8)\end{array}$ & $\begin{array}{c}1 \\
(1.8)\end{array}$ & 56 \\
\hline $\mathrm{m}, \mathrm{sm}$ & $\left.\begin{array}{c}36 \\
(54.5)\end{array}\right]$ & {$\left[\begin{array}{c}11 \\
*(16.7)\end{array}\right]$} & {$\left[\begin{array}{c}17 \\
*(25.8)\end{array}\right.$} & $\stackrel{2}{(3.0)}$ & $\begin{array}{c}66 \\
(100)\end{array}$ \\
\hline $\mathrm{pm}$ & $\begin{array}{c}53 \\
(28.8)\end{array}$ & $\begin{array}{c}66 \\
(35.9)\end{array}$ & $\begin{array}{c}63 \\
(34.2)\end{array}$ & $\begin{array}{c}2 \\
(1.1)\end{array}$ & $\begin{array}{r}184 \\
(100)\end{array}$ \\
\hline
\end{tabular}

型 (por, sig)の 2 群に分けて検討すると，早期胃癌で は分化型が平均 2.8 個, 低分化型が1.9個と分化型に転 移個数の多い傾向がみられた。逆に pm 癌では分化型 4.1個に対して低分化型8.5個であった（表 2).

2) 深達度別転移リンパ節浸潤様式について

深達度別に図 1 の分類に従ってその頻度を比較する と, m 癌では I 型70\%, II 型 0\%, III型 $20 \%, \mathrm{IV}$ 型10\% で, sm 癌ではそれぞれ $51.8 \%, 19.6 \%, 26.8 \%, 1.8 \%$ となり, pm 癌ではそれぞれ $28.8 \%, 35.9 \%, 34.2 \%$, $1.1 \%$ で深達度が増すほど I 型は少なくなり, II, III型 の占める割合が増加した（表 3 ）。

一方, 早期胃癌のうちでも 2 症例, 各 1 個のリンパ 節はいずれす分化型癌の症例であるが，被膜をこえて 周辺脂肪織に浸潤するIV型を呈していた（図2）.

3）組織型別転移リンパ節浸潤様式について

組織型別では早期胃癌全体の分化型は I 型40\%, II 型20\%, III型35.6\%, IV型4.4\%であるのに対して, 低

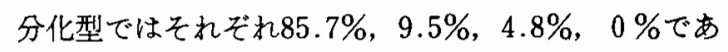
り, 分化型にI型は少なく, II, III型が高頻度であっ た。また pm 癌でも同様に早期胃癌はど著明な差はみ られないが, 分化型に, II, III型の占める割合が増加 した（表 4 ). 
図 2 リンパ節転移巣 $(\mathrm{H} \& \mathrm{E}, \times 100)$ 転移リンパ節 から周辺脂肪織へ癌細胞の浸潤がみられる $\left(\mathrm{tub}_{2}\right)$.

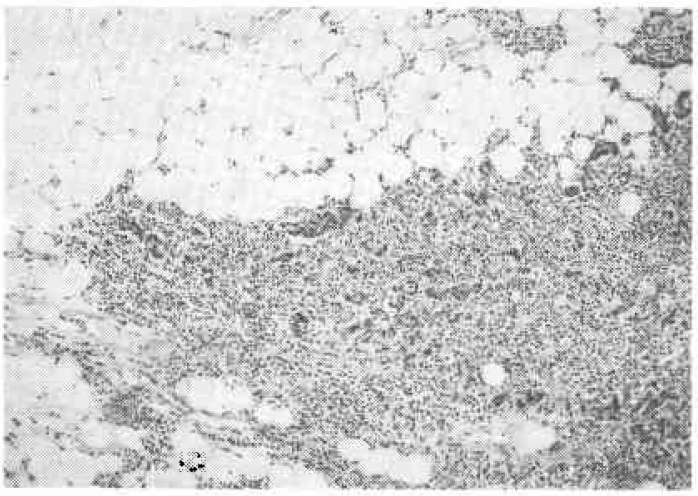

表 4 組穖型別転移リンパ節浸潤様式

\begin{tabular}{|c|c|c|c|c|c|}
\hline & 1 & II & III & N & tt \\
\hline$m$ & 2 & 0 & 2 & 1 & 5 \\
\hline $5 \pi$ & 16 & 9 & 14 & 1 & 40 \\
\hline $\mathrm{m}, \mathrm{am}$ & $\begin{array}{c}18^{*} \\
(40.0)\end{array}$ & $\begin{array}{c}9 \\
(20.0)\end{array}$ & $\begin{array}{c}16 * \\
(35.6)\end{array}$ & $\underset{(4.4)}{2}$ & $\begin{array}{c}45 \\
(100)\end{array}$ \\
\hline $\mathrm{pm}$ & $\begin{array}{c}28 \\
(24.1)\end{array}$ & $\begin{array}{c}40 \\
(34.5)\end{array}$ & $\begin{array}{c}18 \\
(41.4)\end{array}$ & 0 & $\begin{array}{c}116 \\
(100)\end{array}$ \\
\hline
\end{tabular}

\begin{tabular}{|c|c|c|c|c|c|}
\hline & I & al & III & IV & It \\
\hline $\mathrm{m}$ & 5 & 0 & 0 & 0 & 5 \\
\hline $\mathrm{sm}$ & 13 & 2 & 1 & 0 & 16 \\
\hline$m_{t} \mathrm{sm}$ & $\begin{array}{c}18 \\
(85.7)\end{array}$ & $\begin{array}{c}2 \\
(9.5)\end{array}$ & $\begin{array}{c}1 \\
(4.8)\end{array}$ & 0 & $\begin{array}{c}21 \\
(100)\end{array}$ \\
\hline $\mathrm{pm}$ & $\begin{array}{c}25 \\
(36.8)\end{array}$ & $\begin{array}{c}\mathbf{2 6} \\
(38.2)\end{array}$ & $\begin{array}{c}15 \\
(22.1)\end{array}$ & $\begin{array}{c}2 \\
(2.9)\end{array}$ & $\begin{array}{c}68 \\
(100)\end{array}$ \\
\hline
\end{tabular}

() 8

\section{考察}

胃癌の転移形式としてはリンパ行性, 血行性および 播種性転移が考兄られる。早期胃癌ではリンパ節転移 以外に非治癔因子が存在することはきわめてまれであ り，病栄の切除と同時にリンパ節郭清を行觉ばはとん ぞが治癒切除となる。このため進行癌と異なりリンパ 節郭清は重要な意味をもち，従来から多くの報告がみ られる.早期胃癌のリンパ節郭清は $R_{2}$ を標準術式とす る意見(6) 8)が多いが，最近では診断技術の進歩々同時 にリンパ節の免度学的な立場からリンパ節の温存を考 慮すべさであるとの意見や9110)，さらにある条件下の 早期胃癌では縮小手術 $\left(\mathrm{R}_{1}\right)$ でも十分であるとの報 告1112) 女久られる。

一方，早期胃癌の血行性転移に関しては，術前打よ び術中に発見されることはきわめてまれであり，汪と
んどが再発形式としての血行性転移が問題とされてい る. 一般に早期胃癌の再発は, (1)隆起型の $\mathrm{sm}$ 癌, (2)分 化型腺癌, (3)リンパ節転移陽性, (4)脈管侵襲陽性の症 例に多くみられ，再発形式としては血行性転移（肝転 移)が最も多いと述べられている1) 。市た再発部位に

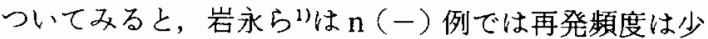
ないがほとんぞは肝再発であり， $\mathrm{n}(+)$ 例では肝再発 のみならずリンパ節，腹膜，局所，骨，皮膚再発と各 種再発部位がみられたと述べ， $\mathrm{n}(+)$ 例ではリンパ行 性だけでなく血行性，局所，腹膜撒布之種々の再発形 式が起こることを指摘している。また高木ら の結果を報告している.

これらの再発症例はほとんどが術前すでに血行性微 少転移 (micrometastasis)を抗こしていたり，リンパ 節郭清が不十分のために起こったと考光られるが，中 には術中操作やリンパ節郭清時に前述の種々の転移が 起こる可能性も十分に考克られる。武藤ら ${ }^{13)}$ は胃癌手 術操作前後での血中癌細胞陽性率について検討してい るが，手術侵襲により腫瘍局所の静脈内に癌細胞の出 現率が増加していたと報告している。.Fisher $5^{14)}$ も結 腸, 直腸癌についての検討で手術操作による癌細胞の 血中撒布を指摘している。蓑岩永ら就術中に癌が 血行性転移を起こさないような対策として，開腹直後 にまず 4 本の主要動静脈の結紮を行うべきであると述 ベている。

われわれは転移リンパ節からの 2 次的波及予防の立 場から, $\mathrm{n}(+)$ 症例を深達度および組織型別に転移り ソパ節の個数ならびに転移リンパ節の浸潤様式にどの ような差がみられるかについて検討し，リンパ節郭清 の際の参考とした。

まず深達度別転移りンパ節数についてみると，当然 のことながら深達度が増すにつれて平均転移リンパ節 数も増加していた，組織型別では早期胃癌に関しては 分化型が平均 2.8 個に対して低分化型が1.9個と分化型 に転移個数の多い傾向がみられた。そこでこれらの転 移リンパ節の浸潤様式について検索を行った。

武藤ら $\left.{ }^{15}\right)$ は転移リンパ節組織像を，1）転移の程度, 2）転移癌細胞の增殖状態，3）癌增殖に対寸る反応之 しての結合織增殖状態より 4 型に分類しているが，わ れわれは主に転移癌細胞の増殖状態より I IV型に分 類して観察した。

潹達度別では深達度が増すにつれてI 型が少なくな り，II，III型の占める割合が多くみられた。しかし早 期胃癌とい壳どあ 2 症例各1個の転移リンパ節はIV型 
を呈しており，郭清には十分注意を要するものと考え られる。

一方, 組織型別比較では分化型は低分化型に比べて 明らかに I 型は少なく， II，III型が高率であった。

ところでリンパ液はリンパ節の凸部から輸入管を通 じてまず辺縁洞内に注ざ，その後髄内洞に入り輸出管 に連絡する、リンパ節への癌細胞の転移も初期には辺 縁洞にのみ転移が扢こり，その後中心部すなわち髄内 洞に向って増殖し，最後にはリンパ節全体に進展する ものと考光られている年). 事夷われわれの成績でも $\mathrm{m}, \mathrm{sm}, \mathrm{pm}$ と深達度の増加とともに I 型が少なくな ク, II, III型の占める割合が増加していた。しかし組 織型別に比較すると，深達度が同じであっても分化型 は明らかにII, III型の占める割合が増加しておう, 進 行度だけでは説明が出来ずこの理由に関しては不明で あるが, 癌の生物学的特性も考慮されねばならないと 思われる，現在までこのような成績に関する報告はみ られず，さらに詳細な検討を要する問題と思われる。

リンパ節から他のリンパ節への転移腫場の広がりは リンパ管を介する経路と, 被膜を破って連続的に隣接 リンパ節に浸潤性に波及する場合とが考えられている が，さらにリンパ節に豊富に存在する血管系を介して 2 次的に転移を扣こす可能性も考えられる。早期胃癌 の再発恃分化型でリンパ節転移陽性例に多いという事 実と，今回のわれわれの成績から判断すると，再発原 因の一部にはリンパ節郭清の際に転移リンパ節から 2 次的に波及した可能性も考慮に入れる必要があるもの と考えられる。

いずれにしても早期胃癌のらち分化型癌は転移リン パ節数が多く，また転移程度も強いため術中の郭清操 作は en block, 広範囲に, しかもリンバ節への圧挫 などをせぬよらに十分な注意が必要と考えられた。

$$
\text { まとめ }
$$

リンバ節郭清の立場から早期胃癌および pm 癌を対 象として, 深達度拉上び組織型別に転移リンパ節の個 数ならびに転移りンパ節の浸潤様式にどのような差が あるかについて検討し以下の結果を得た。

1）深達度に比例して平均転移リンパ節数が増加し た。また組織型別では早期胃癌に関しては分化型に転 移リンパ節数の多い傾向がみられた。

2）転移リンパ節の漫潤様式については深達度が増
すにつれてI 型が少なくなり, II, III型の占める割合 が増加した，組織型別では深達度が同じであっても分 化型は低分化型に比べて明らかにI型は少なく，II, III型が高率であった。

以上のことより早期胃癌のらち分化型癌は転移リン 八節数が多く,またリンパ節転移程度も強いため術中 操作の際には転移リンパ節からの 2 次的波及予防に注 意を要することが示唆された。

\section{文献}

1) 岩永 風, 古河 洋, 多賀一郎ほか: 早期胃癌のリ ンパ節転移と予後。外科 Mook $28: 63-70,1982$

2) 貝原信明, 田村英明, 古賀成昌 : 早期胃癌術後死亡 原因の分析。胃と腸 $19: 739-743,1984$

3）高木國夫, 太田博俊, 高橋知之ほか：外科臨床の立 場からみた早期胃癌再発死。胃と腸 $19: 773$ $-780,1984$

4) 山田栄吉, 紀藤 毅, 鈴木 亮: 早期胃癌の予後. 外科 $41: 346-354,1979$

5）胃癌研究会編：胃癌取扱い規約 (改訂第11版)。金 原出版, 東京, 1985

6）古河 洋, 平塚正弘, 龟山雅男注か：早期胃癌。消 外セミナー $20: 89-99,1985$

7) 太田博俊, 高木國夫, 大橋一郎ほか：早期胃癌 1000 例の検討. 日消外会誌 $14: 1399-1408,1981$

8）鈴木博孝, 遠藤光夫, 鈴木 茂ほか：早期胃癌にお けるリンバ節転移の検討. 日消外会誌 $17: 1517$ $-1526,1984$

9）榊原 宣，梶原哲郎，小川健治ほか：早期胃癌では どこまで郭清すべきか。手術 36：289-294, 1982

10）岡林孝弘：胃癌所属リンパ節の免疫組織化学的研 究。日外会誌 $88: 529-542,1987$

11）大原毅, 城島嘉昭, 定月英一ほか：早期胃癌に対 する維小手術の可能性. 消外 $8: 15-19,1985$

12）北岡久三, 吉川謙蔵, 鈴木雅雄ほか：早期胃癌の所 属りンパ節温存手術に関する検討，日癌治療会誌 $18: 969-978,1983$

13）武藤完雄：外科からみた胃癌．金原出版，東京， 1963, p69-85

14) Fisher ER, Turnbull RB: The cytologic demonstration and significance of tumor cells in the mesenteric venous blood in patients with colorectal carcinoma. Surg Gynecol Obstet $100: 102-107,1955$

15）武藤完雄：外科からみた胃癌。金原出版, 東京, 1963, p55-63

16）宮地 徹：臨床組織病理学. 杏林書院, 東京, 1971, p71-111 